\title{
THE THREATS TO NATIONAL SECURITY OF UKRAINE AND POLAND INASSISTING TO THE DEVELOPMENT OF THE CRYPTO-ASSET MARKET: LEGAL ASPECT
}

\author{
Kostenko Svitlana ${ }^{1}$, Strilchuk Vitalii ${ }^{2}$, Chernysh Roman ${ }^{3}$, Buchynska Anna $^{4}$ \\ ${ }^{1}$ PhD, Associate Professor, Department of Science of Law, Polissia National University, Staryi Blvd 7, 10008 Zhytomyr, \\ Ukraine.Phone+380979421195. Email: sveko7@ukr.net \\ ${ }^{2}$ PhD, Associate Professor, Department of Science of Law, Polissia National University, Staryi Blvd 7, 10008 Zhytomyr, \\ Ukraine. Phone +380679487573. E-mail: v.stril4uk@gmail.com
}

${ }^{3}$ PhD, Associate Professor, Department of Science of Law, Polissia National University, Staryi Blvd 7, 10008 Zhytomyr, Ukraine

Phone Number. +380674126814. E-mail:chernyshRF@gmail.com.

${ }^{4}$ PhD, Associate Professor, Department of Science of Law, Polissia National University, Staryi Blvd 7, 10008 Zhytomyr, Ukraine

Received 2307 2020; Accepted 04112020

\begin{abstract}
The article studies the mainstreaming of the crypto assets' market legal regulation on the example of Ukraine and Poland. Specifically, the notions "crypto currency" and "virtual currency" are analyzed. On the basis of dialectical method and of critical analysis of research literature, regulatory legal acts, etc. the impropriety of the stated notions' use is proved, especially as concerns the legislative level; the specifics of the stated categories' legal status is defined; the necessity and practicality of special regulatory legal acts approval in this sphere on the level of Ukraine and Poland is determined, for effective rights' exercising of the corresponding relations participants, including constitutional rights. Simultaneously, the article provides the grounds for inacceptability of adoption by Ukraine and Poland of the crypto assets' market development by means of impelementation of varios benefits (preferences) for this market participants, because this can threaten the ecological, energy, information, and in total, national security of the given states.
\end{abstract}

Key words: crypto currency, national security, virtual currency.

JEL Codes: K24, K33.

\section{Introduction}

The international experience analysis of financial systems' establishment and functioning shows that there appear a number of multifarious questions as to the mainstreaming of cryptocurrency introduction; these questions give rise to heated discussions in many countries of the world. Specifically, these are the issues concerning its legalization, legal status and even determining and development of methods to avoid the threats to states' national security. Thus, for instance, it is worth noting that such a well-known programmer and co-founder of Microsoft Company as Bill Gates, who knows computer programming and algorithms exceptionally well, is sure that the development of crypto currency market is dangerous (Epravda, 2018). Instead, a considerable number of globally famous actors, politicians (Ukrainian ones including (Epravda, 2017), scholars (Iansiti and Lakhani, 2017: 118-127), etc. highlight its introduction into national financial systems and practically use crypto currency.

Therefore, the purpose of this study is to establish the advantages and disadvantages of

Copyright (C) 2021 Author(s), published by Vytautas Magnus University. This is an open access article distributed under the terms of the Creative Commons Attribution Non-Commercial 4.0 (CC BY-NC 4.0) license, which permits unrestricted use, distribution, and reproduction in any medium provided the original author and source are credited. The material cannot be used for commercial purposes. 
cryptocurrency, the essence of the problems of its legal regulation, to clarify its legal status and potential threats in promoting the cryptocurrency market for national security.

The issue of crypto-currencies' functioning was studied in various aspects. Thus, researchers in the field of economics tried to explore whether it was economically beneficial to apply crypto-currency on the market, whether it would facilitate the development of state economy. Scholars in the sphere of law study the legal nature of the corresponding phenomenon, determine the risks, related to crypto-currencies' application, introduce proposals as to the improvement of legal regulation of these legal relations. Representatives of business companies, in their turn, exercise research of the ways of obtaining profits from operations with cryptocurrencies, publishing relevant educational content, conducting trainings, etc. So, among crypto-currencies researchers the following personalities can be specified: Rubanov P. (2015), Piech K. (2017), Nogacki R. (2019), Nekit K. (2018), Kravchuk V. (2012), Kostyuchenko V. (2017), Kacwin M. (2017), Iansiti M. and Lakhani K.R. (2017), Hendrickson J. and Luther W. (2017), Chaplyan S. (2018), Duchenko M. and Pavlenko T. (2018), Levchuk C. (2018) and others.

Thuswise, each of the stated above groups of researchers studies the cryptocurrencies' market in one separate aspect, from the perspective of the interests of this or that scientific sophistication. Simultaneously, the suggested research is a complex one, as the attempt is made in it to analyze and unite the multifarious results obtained, and its final goal is obtaining objective, generalized and new conclusions.

The object of the research is the cryptocurrency market, the subject of the research is the legal regulation of social relations arising in the process of extraction, exchange, and sale of cryptocurrencies, as well as national security through the prism of promoting the cryptocurrency market.

The basis of the research methodology is the dialectical method of scientific sophistication and the method of complex analysis, which enabled considering and exercising the analysis of diametrically opposed views of various researcher groups as to crypto-currency and making new author's conclusions.

With the help of the Aristotelian method and the method of legal norms' interpretation, the sense and plot of the crypto-currency category was analyzed; it was established, that categorial clarification is needed for the name of the relevant phenomenon, especially at the statutory level.

The comparative-legal method was applied in conducting the comparative analysis of the provisions of regulatory legal acts of the EU, Poland, Ukraine and other states, which determine the legal regulation of cryptocurrency.

\section{Research results and discussion}

Before starting the analysis of the given term, with consideration to the volume and subject of the research, we would like to present a brief definition of the "crypto currecncy" notion. Crypto currency is a kind of digital assets, the functioning of which is provided by cryptographic methods and the blockchain technology.

It can be used to pay bills or transactions. At the same time, crypro currency has no central governing body. All operations are checked by the Blockchain network, that is, by other users. Each block consists of chain operations which are interconnected, that is why it is impossible to falsify or cancel an agreement. A crypto currency unit is a code which is produced as the result of complicated computer mathematic calculations. The process of obtaining crypto currency is called mining. It is exercised with the help of expensive special computer equipment. Crypto currency can be exchanged with the help of crypto currency exchange board or via a crypto currency exchange office.

Having cleared the notion "crypto currency" in general terms, it is possible to pass directly to the analysis of "crypto currency" as a term. Before developing effective regulation of any relations, first it is 
necessary to correctly determine the definitions framework.

From the analysis of various research sources and web-based media a clear-cut tendency can be observed that the notion and understanding of cryptocurrency as virtual currency has stricken root. Besides, the notion of digital currency is often used as a synonym. In addition, while the mentioned notions are characterized, the notion of electronic money is often used. To clarify the suggested terminology, each of the mentioned terms will be considered in detail.

Thus, among the mentioned terms the notion of digital currency is the most general. Digital currency can operate as the means of digital expression either of virtual currency (non-fiat currency), or of electronic money (fiat currency), that is why it is often used as the synonym of "virtual currency" (SDFM, 2015: 51). Fiat (fiduciary) currency is understood as the type of money or currency, the value of which originates not from its own value or the exchange guarantee for gold or another currency, but from the state order (from Lat. Fiat - decree, order) to use it as the means of payment; that is, this is the money issued by the central bank or another institution, acknowledged by the state as the legal payment means and having no soecial intrinsic value (Kravchuk, Naumenko and Glybovets, 2012: 5).

To clarify other notions, official publications of international regulation and control bodies, as to this sphere, will be referred to, in particular, correcsponding EU directives, FATF (The Financial Action Task Force), EBA (European Banking Authority) documents, etc.

The official definition of electronic money is provided in to DIRECTIVE 2009/110/EC (Eur-lex, 2009). From his analysis, it becomes clear that the mandatory property of electronic money is that it belongs to fiduciary money, that is it must be recognized by the state as a lawful payment means, and the obligation must be established that it must be admitted in exchange operations like traditional banknotes and coins. Electronic money must be completely maintained by traditional money or by other readily obtainable assets, and on its owner's demand it must be exchanged for usual money. Electronic money systems can be based on smart-cards' use or on special software: electronic money of VISA Cash, Mondex card systems and electronic money of PayPal, GlobalMoney network systems.

In the majority of world states, electronic money emission is strictly controlled by the state, which determines the circle of subjects which are allowed to issue electronic money, as well as emission terms. For instance, in Ukraine the only electronic money producers are banks. Electronic money value can be expressed only in hryvnias (Rubanov, 2015).

According to EBA, "VCs are defined as a digital representation of value that is neither issued by a central bank or public authority ..., but is used ... as a means of exchange ... electronically" (EBA, 2014: 11). So, the European bank body expressly points out that virtual currency, unlike electronic money, is of non-regulated and decentralized character. Further on this document reads that virtual currency may be convertible and nonconvertible. In more detail as to virtual currency kinds, it reads in FATF REPORT Virtual Currencies Key Definitions and Potential AML/CFT Risks (FATF, 2014).

Thuswise, having clarified essential details of the following categories as "digital currency", "virtual currency", "electronic money" and crypto currency", and having revealed differences between them, it is considered practical to conduct a more detailed analysis of the "crypto currency" category on the example of officials documents of relevant international organizations. Thus, the EBA document reads that " ... the usage of the term 'currency' is misleading for several reasons, including the insinuation that it is therefore

Copyright (C 2021 Author(s), published by Vytautas Magnus University. This is an open access article distributed under the terms of the Creative Commons Attribution Non-Commercial 4.0 (CC BY-NC 4.0) license, which permits unrestricted use, distribution, and reproduction in any medium provided the original author and source are credited. The material cannot be used for commercial purposes. 
exchangeable against other currencies, which may not necessarily be the case" (EBA, 2014: 11).

In "Opinion of the European Central Bank" one can read about some remarks as to "virtual currency" definition. Thus, "virtual currencies" "do not qualify as currencies from a Union perspective. ... The euro is the single currency of the Union's economic and monetary union. ... The ECB recommends defining virtual currencies more specifically, ... that virtual currencies are not legal currencies or money" (ECB, 2016: 3).

In the document "Virtual currencies and central banks monetary policy: challenges ahead", a similar idea can be traced: "The term "virtual currency" might be misleading, suggesting that a $\mathrm{VC}$ is a sovereign currency. Instead, they represent a form of private money" (Europarl, 2018).

Hence, international financial organizations admit, that such notions as "crypto currency" and "virtual currency" are inadvisable and misleading. The reason of the application of specifically this misleading notion is clear; it was done for marketing purposes. Indeed, a potential user, on hearing the word "currency", has a certain confidence level as to this unit on a psychological level, as currency, on the example of euro, is accepted and exchanged by everybody. That is why the words "crypto currency" or "virtual currency" produce an already wrong impression as to their essence. A peg to the word "currency" in the name serves a kind of advertisement for expanding the volume of financial operations connected to corresponding units, and this is a fraudulent means of mass influence. So, the mentioned above international public documents emphasize the necessity of applying more exact notions to name the relevant phenomena. However, the difficulty in renaming of already rooted notions under consideration is that the developer of the relevant units, which has his authorship rights, finds the application of precisely these nominations beneficial, and it is impossible to influence his 'creative process' on legal grounds. A single way out of this situation appears to be the non-use of such terms on the legislative level. Thus, in our opinion, a good alternative for the notions "virtual currency" and "crypto currency" is "virtual assets" and "crypto assets" correspondingly, which doesn't result in their distorted understanding.

Thus, ESMA has already taken this way; specifically, in its report "Advice. Initial Coin Offerings and Crypto-Assets" the term "Crypto-Assets" was used (ESMA, 2019), which supports the practicability of our suggestion

That is why, it is deemed expedient to introduce changes on the international legislative level into corresponding regulatory legal acts and change the notion "virtual currency" into the notion "virtual assets", in particular, in the Directive (EU) 2018/843 (Eur-lex, 2018). Actually, in the context of the said above, in the further research the term "crypto assets' will be used.

Internationally, a single special regulatory legal act, allowing standardizing legal regulations of the corresponding market on regional levels, is absent. That is why, states consider crypto assets, from a judicial standpoint, according to their own vision, which, on reviewing the relevant global practice, is rather unhomogenious. For instance, in Canada crypto assets are placed at the same footing as non-material assets, in Argentina - as money and goods, in China - as virtual goods, etc. (Bank, 2017). On the one hand, the absence of a unified global approach makes defining of crypto assets' legal status on the states' level difficult, including Ukraine and Poland. However, on the other hand, it is wrong to consider the absence of a unified regulatory legal act in the EU, regulating the crypto assets-related activity, to be a demerit, considering the following. The stated position in this issue is chosen deliberately; indeed, as early as in January 2016, at the public hearing which took place in the European Parliament as to digital currencies, it was resumed: the situation related to digital currencies must be watched continuously; there is "no special hurry" in regulating financial products connected to digital currencies; hence, it is worth refraining from direct regulation of crypto assets (Eurasiancommission, 2017:5). The stated results are most probably connected with the fact that crypto assets are not secured 
whatsoever (neither with money, not with goods, nor by the state) and are in fact something like a soap bubble which can burst any moment. One of the leading American bank holdings Morgan Stanley expressed its opinion on this point: "A real value of a bitcoin can be equal to a zero, if nobody adopts this technology for exercising payments" (Eurasiancommission, 2017: 1).

The truth of this statement is supported by statistics: thus, in June 2012, when there was no demand for crypto assets, a bitcoin value in relation to a dollar was $\$ 5$, and in 2017 there was the climax of biscoin value growth, as 1 bitcoin cost nearly $\$ 17746$; however, in 2018 a decrease of demand for bitcoins was marked, which influenced its value, and 1 bitcoin cost \$ 3209 (Myfin, 2019).

So, this is the reason why there is no need for international regulation of this activity. Thereat, the EU's intrusion limits to the adjustment of crypo assets' market functioning to current norms of opposing legalization (laundering) of illegally gained incomes and financing terrorism, and also to customer warning as to risks related to purchasing, owning and operating virtual assets.

In considering of the foregoing, and also of the fact that neither Poland, nor Ukraine has adopted a special regulatory legal act regulating the crypto assets' market, to determine crypto assets' legal nature on the level of the mentioned states these assets should be analyzed through a lens of corresponding legal branches, specifically of civil law and fiscal law branches.

It must be noted first of all that generally states keep aside from state legal regulation of civil law aspects of crypto assets' markets functioning, but concerning the fiscal branch the situation is the opposite one. This can be explained by the fact that generally civil law aspects of crypto assets' markets functioning concern exclusively players on the crypto assets' market and their risks, but they do not touch upon state interests. However, the same cannot be said about the fiscal sphere, as states do not want to lose the state budget profit in the form of corresponding taxes. Actually, this is the reason why mostly states regulate only the fiscal sphere of crypto assets' markets.

At present, the relevant issue as to VAT in the territory of the EU is regulated and unified, as in the case of Skatteverket v David Hedqvist (Case C-264/14) the Court of Justice of the European Union established in its decision that operations with virtual currencies (crypto currencies) shall be safe from VAT. Consequently, this decision is mandatory for the Polish Republic. Not for Ukraine, though. And indeed, the Court of Justice of the European Union is the internal legal body of the European Union. It is worth noting, however, that the decision of the Court in the case of Skatteverket v David Hedqvist is grounded on the provisions of the Directive 2006/112/EU on the common tax system as to added value. In Ukraine, the provisions of this Directive must be implemented during 5 years from the date the Agreement on the Association of Ukraine with the EU enters into force (KMU, 2011), that is, after its ratification in 2022.

Nevertheless, even under the current Ukrainian legislation, operations connected with crypto assets' sale cannot be subject to VAT, because a VAT subject shall be pegged to a delivery place which must be situated in the Ukrainian customs area (P.1, Art.185 of the Tax Code of Ukraine); but it is impossible to define the placement or the delivery place of crypto assets.

So, notwithstanding the differences in legal approaches in Poland and Ukraine, the activity connected to crypto assets' sale is VAT-free. The situation with the profits tax is quite different. Thus, in Poland a general consensus is adopted, according to which any activity connected to crypto assets' mining shall not be subject to the profits tax. And indeed, crypto assets, obtained in the process of mining, do not meet the definition of profits

Copyright (C 2021 Author(s), published by Vytautas Magnus University. This is an open access article distributed under the terms of the Creative Commons Attribution Non-Commercial 4.0 (CC BY-NC 4.0) license, which permits unrestricted use, distribution, and reproduction in any medium provided the original author and source are credited. The material cannot be used for commercial purposes. 
according to tax rules. That is why it is correct to state that virtual currencies' mining does not generate any tax liabilities (Nogacki, 2019).

Instead, in Ukraine there exists the legal vacuum as to this question. Thus, the State Fiscal Service of Ukraine (hereinafter - SFS) in its individual tax consultation №282/К/99-99-13-01-02-14/IПК, dated 25.01.2019 stated that as the order of tax practices with cryptocurrency is not established by the fiscal legislation rules, providing an individual tax consultation as to the issues of the stated rules' practical application is impossible.

So, miners are exercising their activity at their own risk and peril. Ukrainian lawyers tend to think that mining should be given the same status as entrepreneurial activity, as it is obtaining the profit from such activity in the future that encourages a person for exercising mining (Art.42 of the Commercial Code of Ukraine). And this is the reason why a miner must pay the profits tax. By the way, in 2014 in the USA a manual was published in which crypto assets were given the same status as private property, and operations with it must be subject for taxation (and mining in particular) (IRS, 2014). It appears that each state has its valid position as this issue is concerned.

As to the profit tax for crypto assets' sale, the positions of Poland and Ukraine in this point coincide, and it is collected in accordance with the usual procedure.

As concerns a civil law aspect of determining crypto assets' legal nature, the analysis of research and judicial literature gives grounds for the conclusion that Ukrainian researchers are of the unanimous opinion to acknowledge crypto assets as objects of the ownership right (and an object of the civil right, accordingly). Despite various approaches as to determining a special object, which has the properties similar to crypto assets, the majority of law researchers tend to think that in a civil law aspect crypto asset, under certain conditions, possess the features of property (Nekit, 2018: 42; Ukrainepravo, 2018; CDN, 2018: 15).

Besides, in the case of Beyeler v. Italy, the European Court of Human Rights [2000] observed that 'the notion 'property' in Art.1
[Protocol 1 to the Convention] has an autonomous meaning which is not limited to property for physical things. It is independent of formal classification in the national law: some other rights and interests, which assets constitute, can be considered as the property right and, in this respect, as 'property' in the context of this provision".

It seems obvious that with the development of new technologies the civil law theory must develop and update, considering present-day tendencies. And indeed, it appears sensible for civil law scholars to consider a new conception acquiring more and more popularity and suggesting that new civil law objects should be singled out, specifically, the "virtual property", which embraces electronic data stored in computers or the Internet network, and includes electronic mail, digital photos, electronic bank account statements, domen names, online bills, etc. (Chaplyan, 2018). It is considered, that crypto assets can also be included into the virtual property list.

In Polish private law science, it is also recognized that according to Art.44 of the Civil Code digital currency is a form of property ("Property is belongings and other property rights") (Piech, 2017: 53).

As with any property, certain risks are characteristic of crypto assets, which are related to such authorities as the right of possession, the right of use and the right of disposition. However, it is worth observing that the risk level, characteristic of crypto assets, is much higher than that of other property kinds, as, for one thing, the crypto assets' market has no regulatory and legal environment. Thus, for instance, in 2016 the Darnytsia District Court of Kyiv brought on a case as to transmission of natural goods obligations (Verdictum, 2016). The plaintiff and the defendant entered an agreement on Bitcoin exchange for works (software development and creation). The plaintiff fulfilled his agreement terms, while the defendant failed to transmit the Bitcoin amount, as was stated in the agreement. The plaintiff appealed to the court, claiming the violation of his rights. But the court did not satisfy the plaintiff's claim, grounding its decision on the fact that the plaintiff had 
wrongly defined his court defense method: according to the national legislation, the Bitcoin digital product has no product attributes. Hence, the plaintiff failed in defending his violated right.

It is worth noting that the plaintiff failed to defend his violated right in the Kyiv Court of Appeal as well. Because of the fact that the stated court agreed with the first-instance court position and confirmed that Bitcoin is not a thing, as understood under Art.179 of the Civil Code of Ukraine, it has no material world attributes and Bitcoin is not a product. Besides, Bitcoin has no property right's attributes (Reyestr, 2016).

So, because of the legal uncertainty of the crypto assets' market in Ukraine, and consequently, difficulties in the court defense of the market members' rights, the latter have no guarantee as to the due court defense of their rights.

Beside the stated facts, the crypto assets' market possesses its own risks. Thus, while exercising operations with crypto assets, there is no mechanisms of operation cancelling, so crypto assets can be returned only by the receiver (owner). In addition, the electronic payment has no retroactive force; it cannot be frozen or blocked. Potential customer risks also include a broad range of price fluctuations per a crypto assets' unit (statistics was introduced above).

However, despite all this, the crypto assets' market continues being in considerable demand both in Ukraine, and in the whole world. So, it can be concluded that this market is developing and it requires no permission from the state for its emission, legalization and so on; it exists beyond legislation in Ukraine, as well as in most states in the world. Crypto assets' exchanges can be regulated, as it is done in the USA, it is possible to grant licences for funds and other organizations working with crypto assets, but crypto assets themselves, in their essence and worldwide, are not controlled and not regulated (Kostyuchenko,
Malinovskaya and Mamonova, 2017). Certainly, the crypto assets' market can be prohibited within one state, if it is recognized illegal and severe sanctions can be implemented. Thus, in Bangladesh, for example, those caught using bitcoin could spend up to 12 years in prison (Hendrickson and Luther, 2017: 188-195). However, such severe methods in world politics as to the crypto assets' market are rather an exception than a rule, and neither Ukraine, nor Poland belong here.

That is why the states where the crypto assets' market is in function, should recognize them as digital (virtual) assets, regulate the taxation system for crypto assets' operations, introduce the methodology of maintaining records of these operations, and also determine within the regulatory legal framework their definite civil law status, for effective realization of consumers' rights for court defense.

Alongside the need of the state-level determination of crypto assets' status, there appears another logical question: should the states, applying legal means, incite the development of the crypto assets' market; indeed, quite a few economists consider that the stated developed market can put on a whole new quality level both economic entities and states on the whole (Kacwin and Piech, 2017; Duchenko and Pavlenko, 2018)? Thus, for instance, up to recent time, the Draft Law on Incentivization of the Market of Crypto currencies and Their Derivatives (the Draft was withdrawn on 29.08.2019) was registered in Ukraine, under which the establishment of allowances for electricity bills for miners was presumed, with the taxation of the corresponding activity, etc. At present, a draft law on crypto currency taxation № 2461 is registered, under which a $5 \%$ profits tax rate is suggested for physical entities for crypto assets' sale, for a 5-year term. To compare: for the majority of citizens the profits tax rate for physical entities is $18 \%$.

Copyright (C 2021 Author(s), published by Vytautas Magnus University. This is an open access article distributed under the terms of the Creative Commons Attribution Non-Commercial 4.0 (CC BY-NC 4.0) license, which permits unrestricted use, distribution, and reproduction in any medium provided the original author and source are credited. The material cannot be used for commercial purposes. 
To give an unambiguous answer to the stated above question, these mainstreams should be considered from a transcendental position, in the aspect of long-term perspectives. And indeed, only such approach gives the possibility to observe that the crypto assets' market incentivization bears the threat to ecological, energy, information, and generally, national security of the state.

The threat to ecological safety of the states consists in the following. In 2015 at the UNO summit, the Resolution was approved and 17 Sustainable Development Goals were adopted. Among other things, the Resolution read about the sustainable development provision in its three dimensions - economic, social, and ecological - to be conducted in a balanced and complex manner ... as social and economic development depend on the rational use of our planet's natural resources. As to the issue of our interest, this idea finds its explanation in Goal 12, where the following task is established: to rationalize the noneffective subsidy of fossil fuels' use facilitating its wasteful use ... aimed at considering its effect on the environment ... (SDG, 2015). In other words, the Resolution states clearly, that the use of fossil fuels has a negative effect on the environment, that is why its wasteful use must be minimized.

The matter is that mining requires a tremendous amount of energy, and the majority of this requirement in electric energy during mining is covered with the help of electric current, generated from fossil fuels. More than a half of bitcoin mining infrastructure is concentrated in China, the power industry of which depends mostly on coal (Saakov, 2017). Hence, the crypto assets' market incentivization will not provide any sustainable development in three dimensions economic, social and ecological - and, consequently will contradict the UNO Sustainable Development Goals.

As to the threat to states' energy safety, it is worth to note the following. Despite the fact that Iceland, due to its cold climate and its numerous renewable energy sources (mostly geothermal and hydro-electric energy sources), is a global mining leader, and this explains the location of one of five global Mining Farms in its territory, this state faced the energy safety threat problem. Thus, within the recent years in Iceland the functioning of great centers of information processing and crypto currencies mining was organized. Considerable reserves of the state's energy resources started to be used on the stated above activity. According to Snorri Sigurbergsson, the leader of Hitaveita Sudurnesja Company, in the nearest future the electric energy consumption by mining centers can climb above the energy consumption of the whole population of the state (Levchuk, 2018). In China, too, crypto assets' mining began to influence negatively general indices of energy consumption. Thus, in some regions the demand on electric energy grew rapidly. Considering this fact, the leadership of the state approved the decision on limiting the electric energy delivery when it was used for mining (Vishnevskiy, 2018).

During 2017, in the course of bitcoin mining more electric power was consumed than, in the average, by 159 world states (Rethink, 2018). As of July 2019, in the global scale, only bitcoin mining required the use of electric power in the amount, equal to general requirements of the population and industry of Switzerland - about 60 terawatt-hours, which constitutes more than $0.2 \%$ of globally produced energy (UNIAN, 2019).

Summing up, the conclusion can be made that with each coming year the stated problems will become more and more topical. This is determined by the growth of the miners' number, which, in its turn, will lead to the complexity of mathematical problems, the work of energy-intensive equipment and, as the result, to the growth of consumed electric power amount.

Actually, this is the reason of the situation that if on the level of states, the mechanism of incentivization of the crypto assets' market development is fixed, the states like Ukraine or Poland, where the level of alternative energy sources development is not satisfactory, will face a real threat of their states' energy safety.

As to information safety, during 2017 2020 in Ukraine the growth of illegal activity is marked in the direction of creating information safety threats with the use of 
cyber-attacks. Thus, viruses like "WannaCry" and "Petya.A" were distributed by hackers, which in Ukraine were aimed at activity blocking and information obtaining which circulated in governmental and commercial structures. Resulting from realized attacks, during various periods the activity of such structures as Boryspil Airport, the ChNPP, Ukrtelecom, Ukposhta, Oshchadbank, Ukrzaliznytsia, Ukrenergo, etc. was blocked. The attacks took place while the software was being updated; as the result the changes' introduction was exercised into system libraries of Windows operational system and the so-called 'back-door' was created.

The problem issue of discovering and neutralization of the mentioned above viruses is the fact that they do not block the PC work. Their main target is engagement of calculating technique into mining. Besides, the said above does not exclude the possibility of copying the PC data and documents placed on it, with the following transferring them to relevant ftpservers.

Threats to national security in Ukraine, as well as worldwide, are essential in the extreme, considering terroristic activity. At present, an important task for the national security bodies, specifically, of Ukrainian ones, is opposing the financial support of such activity. However, the issue of opposing virtual assets' use for terroristic activity financing is rather a complicated, and sometimes, an unrealistic task. This is conditioned by the anonymous character of the relevant operations, the impossibility of blocking them, etc. (Onyshchuk, Petroye and Chernysh, 2020). However, sometimes such activity is successful. Thus, in May 2018, the Svyatoshyno Regional Court in Kyiv found guilty an organizer of a criminal group which, among other things, financed illegal armed groups "Lugansk People's Republic/Donetsk People's Republic" (LPR/DPR) by means of 'crypto assets' conversion into money means in the territory of Ukraine and transferred them to the uncontrolled territory. ... On the results of the corresponding court case, the organizer of the criminal group redressed the damage done to the state in the total amount of $1.1 \mathrm{mn}$ hryvhias (NAPU, 2018).

However, discovery and accountability for perpetrators of financing terrorism by means of crypto assets' use is rather an exception than a rule, and notably, in the global scale. This is indeed the reason, that, understanding the threat to the national security of states and the whole world, the Directive (EU) 2018/843 (Eur-lex, 2018).

Of interest is the proposition of the French economist Thomas Piketty, who suggested that the European Union and America should implement a financial assets' register, which will enable tracing the property owned by definite persons, including electronic assets, with the purpose of fighting against fraud and tax evasion (Piketty, 2014). Developing his thought, it should be noted that the creation of such global register seems to be an unlikely task and the one which can arise a number of disputable questions, including those in the sphere of law. However, the creation of a global register exclusively for crypto assets for opposing funds legalization and terrorist financing, with consideration to a high criminality rate related to the crypto assets' market, appears to be quite a sensible idea, which should be implemented into practice.

The idea as to opposing funds' legalization and terrorist financing, suggested by a froup of authors, appears to be sensible too; it consists in creating a system of automated teller machines for exchanging crypto assets, which could provide transparency and customer identification, as well as in the suggestion to define a client's reliability considering transactions' limit amounts (Vovchenko, Tishchenko, Epifanova and Gontmacher, 2017: 40).

Copyright (C 2021 Author(s), published by Vytautas Magnus University. This is an open access article distributed under the terms of the Creative Commons Attribution Non-Commercial 4.0 (CC BY-NC 4.0) license, which permits unrestricted use, distribution, and reproduction in any medium provided the original author and source are credited. The material cannot be used for commercial purposes. 


\section{Conclusion}

Hence, taking all these points together, the following conclusions can be made. Ukraine and Poland should determine the crypio assets' legal status on the legislative level for exercising constitutional rights of the crypto assets' market participants, and namely, those under which human and citizen's rights and freedoms shall be defended by court (Art.55 of the Constitution of Ukraine), nobody shall be unlawfully deprived of the property right, the right for provate property shall be inviolable (Art.41 of the Constitution of Ukraine) The corresponding constitutional rights are provided in each democratic state.

On the legislative level the terms "crypto currency" and "virtual currency" should be forbidden for use, as they make a false impression as to their essense. And this is why changes should be introduced to previously approved regulatory legal acts of the EU, as well as of Ukraine and Poland, where the notions "crtypto currency" and "virtual currency" are enshrined, substituting them with the terms "crypto assets" and "vitual assets' accordingly.

Simultaneously, states should safeguard their sovereign national interests. That is why, despite certain possibilities - short-term investment perspectives for a state while the crypto assets' market is developing, - the stated market incentivization on the legislative level must be approached carefully, as the consequences of such actions can have a negative impact on ecological, energy, information and, generally, national security of states, specificallyas concerns both Ukraine and Poland.

\section{References}

Vdoskonalennia mekhanizmu zabezpechennia Bank (2017). Komentar zastupnyka Holovy NBU Oleha Churiia shchodo statusu Bitcoin v Ukraini. - Retrieved from https://bank.gov.ua/news/all/5475f47e3c4e33c2687105ae2176139e [2020 09 15].

CDN (2018). Zelena knyha "Rehuliuvannia rynku kryptovaliut”. - Retrieved from https://cdn.regulation.gov.ua/fe/5b/20/42/regulation.gov.ua_Зелена-Книга.-Ринок-Криптовалют.pdf [2020 09 15].

Chaplyan S. (2018). PRAVOVA PRYRODA KRYPTOVALIUT. - Retrieved from https://jusguard.com.ua/uk/publications/legal-nature-of-cryptocurrency [2020 09 15].

Duchenko M. and Pavlenko T. (2018). Vplyv kryptovaliut na ekonomiku krainy. // Ekonomika ta suspilstvo. Vol.2. - Retrieved from http://economyandsociety.in.ua/journal/19_ukr/150.pdf [2020 09 15].

EBA (2014). EBA opinion on "virtual currencies". - Retrieved from https://EBA-Op-2014-08 Opinion on Virtual Currencies.pdf [2020 09 15].

ECB (2016). OPINION OF THE EUROPEAN CENTRAL BANK on the prevention of the use of the financial system for the purposes of money laundering or terrorist financing - Retrieved from https://www.ecb.europa.eu/ecb/legal/pdf/en_con_2016_49_f_sign.pdf [2020 09 15].

Epravda (2018). Kryptovaliuty pryzvodiat do smertei - Bill Heits. - Retrieved from https://www.epravda.com.ua/news/2018/02/28/634554/ [2020 09 15].

Epravda (2018). Shcho zh tse "bitkoitsia", abo u koho z vlady naibilshe kryptovaliuty. - Retrieved from https://www.epravda.com.ua/publications/2017/10/31/630655/ [2020 09 15].

ESMA (2019). Advice Initial Coin Offerings and Crypto-Assets. - Retrieved from https://www.esma.europa.eu/sites/default/files/library/esma50-157-1391_crypto_advice.pdf [2020 09 15].

Eurasiancommission (2017). REHULYROVANYE KRYPTOVALIUT YSSLEDOVANYE OPHTA RAZNЫKH STRAN.

Retrieved from http://www.eurasiancommission.org/ru/act/dmi/workgroup/Documents/digest/Регулирование\%20криптовалют\%20в \%20странах\%20мира.pdf [2020 09 15].

Eur-lex (2009). Directive 2009/110/EC on the taking up, pursuit and prudential supervision of the business of electronic money institutions. - $\quad$ Retrieved from http://eur-lex.europa.eu/legalcontent/EN/TXT/?uri=CELEX:32009L0110 [2020 09 15].

Eur-lex (2018). Directive (EU) 2018/843 on the prevention of the use of the financial system for the purposes of money laundering or terrorist financing. - Retrieved from https://eur-lex.europa.eu/legalcontent/EN/TXT/?uri=uriserv:OJ.L_.2018.156.01.0043.01.ENG\&toc=OJ:L:2018:156:TOC [2020 09 15].

Europarl (20118). Virtual currencies and central banks monetary policy: challenges ahead. - Retrieved from http://www.europarl.europa.eu/cmsdata/149900/CASE_FINAL\%20publication.pdf [2020 09 15]. 
FATF (2014). Virtual Currencies: Key Definitions and Potential AML/CFT. - Retrieved from https://www.fatfgafi.org/media/fatf/documents/reports/Virtual-currency-key-definitions-and-potential-aml-cft-risks.pdf [2020 0915$].$

Hendrickson J. and Luther W. (2017). Banning bitcoin // Journal of Economic Behavior \& Organization. Vol.141: 188-195. - https://doi.org/10.1016/j.jebo.2017.07.001 [2020 09 15].

Iansiti M. and Lakhani K.R. (2017). The Truth About Blockchain // Harvard Business Review - Retrieved from https://hbr.org/2017/01/the-truth-about-blockchain [2020 09 15]. $15]$.

IRS (2014). Virtual Currency Guidance. - Retrieved from https://www.irs.gov/pub/irs-drop/n-14-21.pdf [2020 09

Kacwin M. and Piech K. (2017). Stan rynku kryptowalut w Polsce oraz możliwe przychody podatkowe budżetu państwa. $\quad-\quad$ Retrieved from https://www.gov.pl/documents/31305/436699/Stan+rynku+kryptowalut+w+Polsce.pdf/ceb489cf-aaf5-fdef-fb0462724e1b62b9 [2020 09 15].

KMU (2011). DODATOK XXVIII UHODY PRO ASOTSIATSIIU. - Retrieved from https://www.kmu.gov.ua/storage/app/media/ugoda-pro-asociaciyu/28_Annex.pdf [2020 09 15].

Kostyuchenko V., Malinovskaya A. and Mamonova A. (2017). Peredumovy zaprovadzhennia obliku ta opodatkuvannia operatsii iz kryptovaliutamy v Ukraini // Modern economics. Vol.6: 94-102. - Retrieved from http://nbuv.gov.ua/UJRN/modecon_2017_6_13 [2020 09 15].

Kravchuk V., Naumenko D. and Glybovets A. (2012). Elektronni hroshi v Ukraini. Analitychnyi zvit, Kyiv.

Levchuk C. (2018). Mainery bitkoiniv mozhut zalyshyty Islandiiu bez elektroenerhii. - Retrieved from https://kfund-media.com/majnery-bitkojniv-mozhut-zalyshyty-islandiyu-bez-elektroenergiyi/ [2020 09 15].

Myfin (2019). Hrafyk kursa Bytkoyna za vsiu ystoryiu. - Retrieved from https://myfin.by/crypto-rates/chart-bitcoin [2020 09 15].

NAPU (2018). Vzaiemodiia Sluzhby bezpeky Ukrainy i orhaniv prokuratury shchodo prypynennia protypravnoi konvertatsii kryptovaliuty. - Retrieved from http://napu.com.ua/materialy/protudia_zlochunosti_lisova.pdf [2020 09 15].

Nekit K. (2018). PRAVOVYI STATUS KRYPTOVALIUT V UKRAINI TA U SVITI // Yurydychnyi naukovyi elektronnyi zhurnal. Vol.1: 40-42. - Retrieved from http://lsej.org.ua/1_2018/12.pdf [2020 09 15].

Nogacki R. (2019). Czy wykopanie wirtualnej waluty stanowi przychód podatkowy? - Retrieved from https://www.pit.pl/aktualnosci/czy-wykopanie-wirtualnej-waluty-stanowi-przychod-podatkowy-966558 [2020 0915$]$.

Onyshchuk S., Onyshchuk I., Petroye O. and Chernysh R. (2020). Financial Stability and its Impact on National Security State: Organizational and Legal Aspects // International Journal of Economics \& Business Administration (IJEBA). vol. 0(1), pages 353-365. - Retrieved from https://www.ijeba.com/journal/429 [2020 09 15].

Piech K. (2017). Podstawy korzystania z walut cyfrowych, Warszawa.

Piketty T. (2014). Capital in the Twenty-First Century, Cambridge.

Rethink (2018). Mainynh Bitkoinu spozhyv bilshe elektroenerhii, nizh 159 krain svitu. - Retrieved from https://rethink.com.ua/uk/news-and-events/ekologichni-problemi/mayning-bitkoinu-spozhiv-bilshe-elektroenergii-nizh159-krain-svitu [2020 09 15].

Reyestr (2016). Ukhvala apeliatsiinoho sudu mista Kyieva vid 12.10.2016 r. № 753/599/16. - Retrieved from http://www.reyestr.court.gov.ua/Review/62052778 [2020 09 15].

Roman Chernysh, Viktoriya L. Pogrebnaya, Iryna I. Montrin, Tetiana V. Koval and Olha S. Paramonova (2020). Development of Internet communication and social networking in modern conditions: institutional and legal aspects // Revista San Gregorio. $\quad$ Vol. $41 . \quad$ - $\quad$ Retrieved from http://revista.sangregorio.edu.ec/index.php/REVISTASANGREGORIO/issue/view/RSAN41/showToc [2020 11 15].

Rubanov P. (2015). Rozmezhuvannia sutnosti poniat "elektronni hroshi", "virtualni hroshi” ta "kryptovaliuty" // Efektyvna ekonomika. Vol.4. - Retrieved from http://www.economy.nayka.com.ua/?op=1\&z=6026 [2020 09 15].

Saakov V. (2017). Brudnyi bik bitkoin-bumu. - Retrieved from https://www.dw.com/uk/брудний-бік-біткоінбуму/a-41779935 [2020 09 15].

SDFM (2015). Kerivnytstvo po zastosuvanniu ryzyk-oriientovanoho pidkhodu. Virtualni valiuty. - Retrieved from http://www.sdfm.gov.ua/content/file/Site_docs/2016/20160805/rek\%202.pdf [2020 09 15].

SDG (2015). Rezoliutsiia "Peretvorennia nashoho svitu: Poriadok dennyi u sferi staloho rozvytku do 2030 roku" (2015). - Retrieved from http://sdg.org.ua/ua/resources-2/344-2030-2015 [2020 09 15].

Ukrainepravo (2018). KRYPTOVALIUTA V UKRAINI TA SVITI: REHULIUVANNIA, PRAVOVYI STATUS TA OPODATKUVANNIA. - Retrieved from https://ukrainepravo.com/scientific-thought/legal_analyst/kryptovalyutav-ukrayini-ta-sviti-regulyuvannya-pravovyy-status-ta-opodatkuvannya-/ [2020 09 15].

Copyright (C) 2021 Author(s), published by Vytautas Magnus University. This is an open access article distributed under the terms of the Creative Commons Attribution Non-Commercial 4.0 (CC BY-NC 4.0) license, which permits unrestricted use, distribution, and reproduction in any medium provided the original author and source are credited. The material cannot be used for commercial purposes. 
UNIAN (2019). Bitcoin spozhyvaie stilky zh elektroenerhii, yak Shveitsariia. https://www.unian.ua/science/10605519-bitcoin-spozhivaye-stilki-zh-elektroenergiji-yak-shveycariya.html $\quad\left[\begin{array}{lll}2020 & 09\end{array}\right.$ 15].

Verdictum (2016). Rishennia vid 24.03.2016 № 753/599/16-ts Darnytskyi raionnyi sud m.Kyieva. - Retrieved from https://verdictum.ligazakon.net/document/56686444 [2020 09 15].

Vishnevskiy Y. (2018). NAMAINYLY PROBLEMU. HROZYT LY PLANETE ЭNERHETYChESKYI KOLLAPS YZ-ZA BYTKOYNA. - Retrieved from http://www.dsnews.ua/future/golovoy-o-potolok-kak-maynerybitkoina-namaynili-sebe-12012018220000 [2020 09 15].

Vovchenko N., Tishchenko E., Epifanova T. and Gontmacher M. (2017). Electronic currency: the potential risks to national security and methods to minimize them // European Research Studies. Vol. XX, Issue 1: 36-48. - Retrieved from https://www.ersj.eu/repec/ers/papers/17_1_p3.pdf [2020 09 11]. 